Vladimir Ristanović ${ }^{1}$ Nikola Tasić ${ }^{2}$
JEL: E51, F32, E31

DOI: $10.5937 /$ industrija46-17176

UDC: 338.516.45(497.11)

005.332:338.124.2

Original Scientific Paper

\title{
Exchange rate "Pass-through" on prices in Serbia in the post-crisis period
}

Article history:

Received: 15 March 2018

Sent for revision: 4 April 2018

Received in revised form: 10 May 2018

Accepted: 10 May 2018

Available online: 29 June 2018

Abstract: This paper follows a well-known pass-through effect of the foreign exchange rate at the inflation in the economy. Numerous econometric models show the existence of the influence of the foreign exchange rate on inflation. The aim of the paper is to evaluate how strong this effect is and whether the influence of the foreign exchange rate on price in Serbia after the collapse of the global economy is increasing/decreasing. The pass-through effect is assessed in the post-crisis period using the econometric model (ADL methodology). The results show that this effect exists, but that it is far below 1 and that it has been decreasing over time.

Keywords: pass-through effect, exchange rate, inflation

\section{"Pass-through" deviznog kursa na cene u Srbiji u post- kriznom periodu}

Apstrakt: Ovaj rad prati dobro poznati pass-through efekat deviznog kursa na opšti nivo cena u privredi. Brojni ekonometrijski modeli pokazuju postojanje uticaja deviznog kursa na inflaciju. Cilj rada je da proceni koliko je jak taj efekat i da li se uticaj deviznog kursa na inflaciju u Srbiji nakon izbijanja globalne ekonomske $i$ finansijske krize povećava/smanjuje. Efekat passthrough se procenjuje u post-kriznom periodu koristeći ekonometrijski model (ADL metodologija). Rezultati pokazuju da ovaj efekat postoji, ali da je daleko ispod $1 \mathrm{i}$ da se tokom vremena smanjuje.

Ključne reči: pass-through efekat, devizni kurs, inflacija

\footnotetext{
${ }^{1}$ Faculty of Business Economics and Entrepreneurship, vladimir.ristanovic@vspep.edu.rs

${ }^{2}$ National Bank of Serbia, Faculty of Business Economics and Entrepreneurship 
Ristanović V., Tasić N.: Exchange rate "Pass-through" on prices in Serbia in the...

\section{Introduction}

The main objective of this paper is to assess the effect of shocks in the changes of the foreign exchange rate on price in Serbia, i.e. assessment of the pass-through effect of the foreign exchange rate on the prices after the collapse of the global economy. Our goal is to see if the effect has changed its impact during the crisis and to see the real causes. The analysis of the passthrough effect, from the macroeconomic point of view, has significant implications in the economy. First, it provides a more precise forecast of inflation in the coming period. Second, it also helps in the selection of the foreign exchange rate policy, as well as the choice of instruments of monetary policy. We will try to analyze the interdependence between the foreign exchange rate and the prices in the analysis of the pass-through effect, and evaluate the effect of the foreign exchange rate on inflation.

More recently, the policy of the foreign exchange rate has been given another, very important function, the foreign exchange rate in the function of the stabilization process of transformation of the economy into a market economy. Numerous former communist (closed) states in the initial phase of the stabilization process have opted for the use of the foreign exchange rate as a nominal anchor. As such, the foreign exchange rate has illustrated strong links between inflation and exchange rate, which was particularly evident in the Eastern European countries. The significance of the analysis of the passthrough effect in Serbia is especially important since the changes in the foreign exchange rate traditionally represented a strong signal for the behaviour of business of individual. The transmission mechanisms in monetary policy were mostly carried out through a foreign exchange rate during the 1990s.

Table 1. Comparisons and earlier results of the foreign exchange rate passthrough on CPII

\begin{tabular}{|l|c|c|c|c|}
\hline & $\begin{array}{c}\text { Petrović and } \\
\text { Mladenović (2005) }\end{array}$ & $\begin{array}{c}\text { Vilaret and Palić } \\
(2006)\end{array}$ & $\begin{array}{c}\text { Tasić } \\
(2008)\end{array}$ & $\begin{array}{c}\text { Ristanović and } \\
\text { Tasić (2018) }\end{array}$ \\
\hline $\begin{array}{l}\text { Short } \\
\text { term }\end{array}$ & 0.28 & 0.20 & 0.3 & 0.11 \\
\hline Long term & 0.4 & 0.39 & 0.6 & 0.14 \\
\hline
\end{tabular}

Source: Authors' calculations

Previous analyses of the pass-through effect in Serbia, covering the period up to 2007, showed a significantly higher level of influence of the foreign exchange rate on prices. This is understandable regarding that liberalization has led to faster opening up of the economy and adopting market rules for the foreign exchange rate creating. Oscillations of the foreign exchange rate in 
Ristanović V., Tasić N.: Exchange rate "Pass-through" on prices in Serbia in the...

the transition period required larger interventions and a different exchange rate policy than before. At the same time, the higher price level in Serbia compared to trading partners was more sensitive to oscillations in the exchange rate.

The structure of the paper consists of four additional chapters. In the next chapter, the theoretical aspect of the analysis of the pass-through effect of the foreign exchange rate on inflation will be presented. The third chapter will show the methodology as well as the available data. The results of the empirical analysis will be presented in the fourth chapter, while in the last chapter we will give concluding considerations of the effect of the foreign exchange rate on inflation in Serbia.

\section{The concept and significance of the analysis of the "pass- through" effect of the foreign exchange rate on inflation}

The goals of the monetary policy are best explained by monetary theory through the transmission mechanisms, where monetary effects are considered on the financial system and the real sector of the economy. The intensification of the process of globalization greatly increases the complexity, but also the number of transmission mechanisms. Over time, those transmission mechanisms that exert greater effects on the real sector are of special importance. Under such conditions, the complexity of creating economic policy is growing. These mechanisms are realized through several channels, and in the following we will focus on the mechanism that is most characteristic for the Serbian economy.

The assessment of the impact of shocks on the movement of the foreign exchange rate and import inflation on domestic inflation is a mechanism called a pass-through effect. This mechanism is one of the main challenges for monetary authorities, as it exerts a direct influence on the general level of prices (inflation) in the economy. The pass-through effect is particularly emphasized in economies where the central bank applies an inflation targeting strategy. This is, in particular, characteristic of open economies in which the foreign exchange rate is extremely sensitive to foreign capital flows. Monetary (inflationary) goals then become unfulfilled precisely because of the shocks in association with the fluctuation of the foreign exchange rate.

In addition to the controlled prices, inflationary expectations and external shocks, fluctuations in the foreign exchange rate are a significant factor influencing inflation in Serbia. Inflation is very sensitive to the changes in the foreign exchange rate in the Serbian economy, and it has forced the monetary authorities to start the process of macroeconomic stabilization with the foreign exchange rate being used as a nominal anchor in the collapse of inflationary 
Ristanović V., Tasić N.: Exchange rate "Pass-through" on prices in Serbia in the...

pressures. At the end of 2000 , this is being implemented and is struggling with high inflation rates (decrease from $111.9 \%$ in 2000 to $15 \%$ in 2002). In October 2000, the official exchange rate and market exchange rate were equalized, leaving the Serbian Central Bank to abandon the fixed foreign exchange rate policy. A de jure regime was administered by the fluctuating exchange rate, which, in parallel with the liberalization of prices, resulted in the increase in expected inflation and the growth in money demand.

At the end of 2002, the monetary authorities used the foreign exchange rate as a nominal anchor, which, despite the strong real appreciation of the domestic currency, as well as in other transition countries, influenced the collapse of inflationary expectations.

The impact of fluctuations of foreign exchange rate on inflation can be direct and indirect. Direct effects have their impact in two directions: (1) there is a change in the price of import inputs (used in production), and thus change production costs, which then reflect on the consumer price and thus the general price level; and (2) there is a direct change in the price of imported final products, and hence the general level of prices. Both indirect effects reflect their impact in two directions: (1) there is a change in demand for domestic substitutes for imported products, which change the volume of domestic production, and hence the level of demand for labour, as well as wages that directly affect the general price level; (2) there is a change in the demand for exports, and therefore in the export prices and the price of the substitutes, and finally the change in the general price level. In other words, through the direct channel depreciation of the domestic currency is associated with the growth of prices of import goods, while through the indirect channel depreciation of the domestic currency is associated with the fact that domestic products become relatively cheaper compared to the foreign ones, which consequently has the growth of net exports, and therefore aggregate demand (See also European Central Bank, 2017).

In order to determine the pass-through effect, it is necessary to answer what is the effect of the foreign exchange rate changes on prices in an economy? Numerous empirical analyses have shown that a one-percent increase in the foreign exchange rate does not lead to price changes of one percent, at least not in the short term, although macroeconomic models related to projections of balance of payments movements presume this. This phenomenon in the literature is also known as an incomplete pass-through effect. Nakamura and Zeron (2010) show numbers of factors in causing incomplete pass-through of foreign exchange rates to prices in short and long run. Kasa (1992) shows incomplete pass-through in the short term. Decomposition of the sources of incomplete pass-through on price was introduced by Hellerstein (2008). Frankel, at al (2005) show incomplete pass-through in developing countries. 
Ristanović V., Tasić N.: Exchange rate "Pass-through" on prices in Serbia in the...

Broadly speaking, the pass-through effect is defined as a percentage increase in prices resulting from a one-percent change in the nominal exchange rate. In addition, the strength of the pass-through effect depends on the size and degree of openness of the economy. Empirical studies have shown that a stronger effect of the foreign exchange rate on inflations in less developed part of the World. The liberalization of the foreign exchange market and the transition from a managed to a fully fluctuating exchange rate in many countries have resulted in a weakening of the pass-through effect. Kandil and Mirzaie (2003) explain anticipated and unanticipated components of the movements in the foreign exchange rate in a sample of 33 developing countries. Bailliu and Fujii (2004) suggest that pass-through to import, producer, and inflation declined following the inflation stabilization in developed part of the World in the early 1990s. A similar analysis of the example of Serbia during 1990s showed Petrović and Mladenović (2015) in their paper. Aghion, at al (2006) show that the effect exchange rate volatility depends critically on a country's level of financial development.

The analysis of the pass-through effect has very significant implications on the decision-making process in the area of monetary policy, especially if the economy simultaneously encounters inflation problems and the current account deficit. For monetary policy makers, it is important to have a clearer picture of the impact of sudden exchange rate fluctuations on prices, both in terms of the strength and the duration of that effect. Therefore, a more precise analysis of the effect of a foreign exchange rate on price movements can help monetary authorities in choosing appropriate measures and monetary policy instruments. Monacelli (1999) shows, in the case of a small open economy with an incomplete exchange rate pass-through, that the performance of simple monetary rules can be improved. Also, Smets and Wouters (2002) explain incomplete exchange rate pass-through for optimal monetary economy in the Euro Area. Adolfson (2007) presented incomplete exchange rate pass-through throught an inflation targeting model in monetary theory, while Sutherland (2002) looks at the effects in incomplete foreign exchange rate pass-through for optimal monetary and exchange rate policy. The empirical analysis in chapter 4 showed that in Serbia, during the crisis years, fluctuations in the foreign exchange rate, and even fluctuations in prices, far less, which means that monetary authorities are facing the weakening of the pass-through effect.

Unlike the analysis of other authors (Petrović and Mladenović, 2005; Vilaret and Palić, 2006), who also achieved the existence of the influence of foreign exchange rate fluctuations on the level of price in the Serbian economy, our results show a weakening of the pass-through effect, i.e. reducing the impact of foreign exchange rate fluctuations on inflation (Table 3). This is explained by the fact that, caused by the global crisis, there was a greater degree of intervention in the foreign exchange market by monetary authorities and a 
Ristanović V., Tasić N.: Exchange rate "Pass-through" on prices in Serbia in the...

trend of lower growth rates of consumer prices in the economy. The cause of these circumstances should be attributed to deflationary pressures, both domestic and external, and as a result of the reduction in aggregate demand. The effects of the undertaken monetary measures go beyond the traditional ones, conservative measures and instruments of monetary policy that do not give the desired results in the conditions of the world crisis, such as exchange rate, interest rate, and monetary aggregates. The unconventional measures of monetary authorities do not favor traditional mechanisms that we are accustomed to and distort the picture of monetary indicators.

\section{Data and methodology}

In the empirical examination of the pass-through effect of the foreign exchange rate on inflation, we used the ADL ("autoregressive distributed lag") model, often used methodological concept for similar analysis. Before we introduce the empirical strategy, in the following section, we describe the data that we will use.

\subsection{Data}

The data include the period from January 2007 to March 2016. Although the data for relevant macroeconomic variables are available for the period prior to 2001 (since January 1997), they are excluded from our analysis because they contain a lot of structural breaks. Also, please note that data is not seasonally adjusted.

\section{Table 2. Definitions of variables}

\begin{tabular}{ll}
\hline Notation & Definitions \\
\hline$\pi^{C P}$ & Consumer price index \\
$\pi^{*}$ & Foreign prices (derived as weighted average CPIs in the United States \\
& and the European Union, with weights of $30 \%$ and $70 \%)$ \\
& Generic variable that takes the value of 1 if the dinar has appreciated, and \\
& which takes the value of 0 otherwise (this variable is constructed using the \\
& nominal effective foreign exchange rate as well as the real effective \\
& exchange rate) \\
& Nominal effective foreign exchange rate (derived as weighted index \\
& RSD/EUR and RSD/USD, with weights of $70 \%$ and $30 \%)$ \\
\hline
\end{tabular}

Note: all variables used in regression analysis are logarithmically transformed.

The table 2 presents the notation and definitions of the variables, while the next graph shows the monthly growth of the nominal effective exchange rate. Table 2 helps us to understand how the variable $D$ is constructed, but also indicates relatively small fluctuation in the foreign exchange rate. Such 
Ristanović V., Tasić N.: Exchange rate "Pass-through" on prices in Serbia in the...

changes potentially cause the inability to determine the correlation with the other variables.

Figure 1. Fluctuations in the foreign exchange rate (monthly growth)

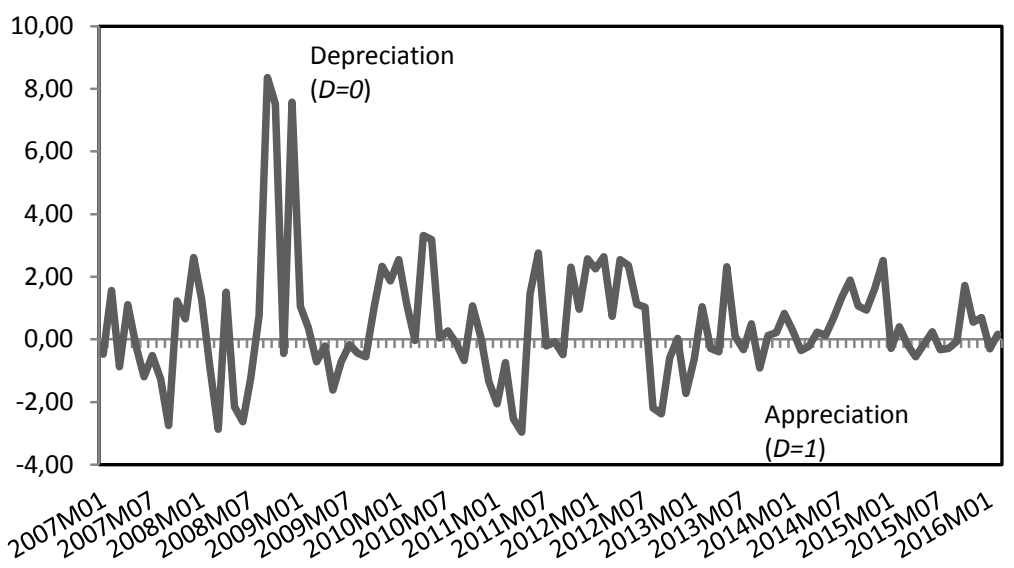

Source: Authors' calculations

\subsection{ADL methodology}

Following the analysis in Vilaret and Palić (2006), we estimate the following equation:

$\Delta \pi_{t}=\alpha+\beta\left(\Delta e_{t}+\Delta \pi_{t}^{*}\right)+\sum_{i=1}^{k} \gamma_{i} \Delta \pi_{t-i}+\varepsilon_{t}$

where $\pi$ or $\pi^{*}$, depends on the model specification, $\varepsilon$ is an error, while the other variables are defined as in Table 1 . The estimated coefficients from the equation (1) were calculated using the smallest squares method, but in order to correct autocorrelation and potential heteroscedasticity, standard errors were constructed using the method recommended in Newey and West (1987). Since preliminary tests could not dismiss the hypothesis that variables are non-stationary, the first variations of these variables were used, as we see in the equation (1). By using the ADF ("augmented Dickey-Fuller") single-root test, we have established that the series of the retail prices, base prices and commodity prices, as well as the nominal effective exchange rate, are of the first order integrated and the differentiation achieves their stationarity. Our basic approach involves multiple regression of time series of each dependent 
Ristanović V., Tasić N.: Exchange rate "Pass-through" on prices in Serbia in the...

variable with the lag (of two months). The short-term pass-through exchange rate is given by $\beta$, while the long run pass-through of the foreign exchange rate is derived as:

$\frac{\beta}{1-\gamma_{1}-\cdots-\gamma_{k}}$

To control the pass-through effect of the foreign exchange rate for the effect of appreciation or depreciation of the foreign exchange rate, we have estimated the following equation:

$\Delta \pi_{t}=\alpha+\beta\left(\Delta e_{t}+\Delta \pi_{t}^{*}\right)+\sum_{i=1}^{k} \gamma_{i} \Delta \pi_{t-i}+\delta D_{t}\left(\Delta e_{t}+\Delta \pi_{t}^{*}\right)+\varepsilon_{t}(2)$

This assessment will allow us to establish the difference between the shortterm (or the long-term) pass-through effect in the period of depression and in the period of appreciation. Namely, the effect $\left(\Delta e+\Delta \pi^{*}\right)$ on $\Delta \pi$ is now given as:

$\frac{\partial \Delta \pi_{t}}{\partial\left(\Delta e_{t}+\Delta \pi_{t}^{*}\right)}=\beta+\delta D_{t}$

Let's recall that $D$ is equal to 1 if RSD appreciates and 0 if RSD depreciates. Therefore, the short run pass-through effect of the foreign exchange rate is given by the estimate of the parameters $\beta+\delta$ if the dinar is appreciated, and the estimate of the parameter $\beta$ if RSD depreciated. Similarly, the long run "pass-through" effect of the foreign exchange rate is derived as:

$\frac{\beta+\delta}{1-\gamma_{1}-\cdots-\gamma_{k}}$

if the dinar has appreciated, and as:

$\frac{\beta}{1-\gamma_{1}-\cdots-\gamma_{k}}$

if the dinar has depreciated. Also, dummy variable D was constructed using 2 different methods - using the appreciation of the foreign exchange rate and appreciation of the real foreign exchange rate. Estimates were repeated for each specification of a dummy variable $\mathrm{D}$.

In addition to the equations (1) and (2), we estimate equations where $D$ is involved without interaction with $\left(\Delta \mathrm{e}_{\mathrm{t}}+\Delta \mathrm{\Pi}_{\mathrm{t}}^{*}\right)$. Also, we have evaluated the 
Ristanović V., Tasić N.: Exchange rate "Pass-through" on prices in Serbia in the...

equation (1) independently for the period when $D$ is equal to 1 and when $D$ is 0 . However, due to conciseness, these results are not presented in the paper.

\section{Results and discussion}

The methodology shown in section 3.2 is applied to the monthly data and the results are shown in Table 3 . The first two lines represent estimates of the short-term and long-term pass-through effects obtained using the starting model from the equation (1). The rest of the results in Table 3 were obtained using the model from the equation (2).

Table 3: Effect of foreign exchange rate on consumer and producer prices, monthly data

\begin{tabular}{|c|c|c|}
\hline & Consumer prices & Producer prices \\
\hline \multicolumn{3}{|c|}{ The effects of the change in the foreign exchange rate } \\
\hline Shor-term & $0.1051^{*}$ & 0.092 \\
\hline Long-term & $0.1412^{*}$ & 0.046 \\
\hline \multicolumn{3}{|c|}{ Effects during depreciation of the foreign exchange rate } \\
\hline Shor-term & $0.1592^{\star *}$ & -0.4619 \\
\hline Long-term & $0.1989^{* *}$ & -0.2277 \\
\hline \multicolumn{3}{|c|}{ Effects during appreciation of the foreign exchange rate } \\
\hline Shor-term & -0.0543 & $0.9252^{\star *}$ \\
\hline Long-term & -0.0680 & $0.4512^{* \star}$ \\
\hline \multicolumn{3}{|c|}{ The effects of the change in the effective foreign exchange rate } \\
\hline Shor-term & $0.0804^{*}$ & -0.1174 \\
\hline Long-term & $0.1096^{*}$ & -0.1985 \\
\hline \multicolumn{3}{|c|}{ Effects during depreciation of the effective foreign exchange rate } \\
\hline Shor-term & $0.1758^{* \star}$ & -0.3388 \\
\hline Long-term & $0.2090^{* *}$ & -0.1669 \\
\hline \multicolumn{3}{|c|}{ Effects during appreciation of the effective foreign exchange rate } \\
\hline Shor-term & -0.1094 & 0.0436 \\
\hline Long-term & -0.1301 & 0.0215 \\
\hline
\end{tabular}

Note: Standard errors that are consistent in terms of heteroscedasticity and autocorrelation are calculated following the Newey and West methodologies (1987). * indicates a significance level of 10 percent, while ** indicates a significance level of 1 percent.

Source: Authors' calculations

Comparing the results from the first two rows, we can conclude that the short run pass-through effect is the highest for the prices of tradable goods, while it 
Ristanović V., Tasić N.: Exchange rate "Pass-through" on prices in Serbia in the...

is the lowest for base prices. The estimated short-term pass-through effect for retail prices is between the effect on the base price and the prices of tradable goods. All results are statistically significant at acceptable levels of trust. Comparing our short-term reviews with the same ones in Vilaret and Palić (2006) as in Table 1, we note that the estimates of the pass-through effects are similar. However, the estimate of the pass-through effect for base prices is lower in our case (0.13 compared to 0.20). Vilaret and Palić (2006) do not show the pass-through effect of the foreign exchange rate on the prices of tradable goods.

Looking at the long-term estimate obtained using monthly data, it is clear that pass-through on retail prices is much higher compared to other domestic prices. Long-term pass-through to base prices is still the smallest in comparison to other domestic prices. If we compare long-term reviews with those obtained in Vilaret and Palić (2006), we can estimate that the passthrough effect of the retail price effect is much higher in our case $(0.50$ compared to 0.39 ). In contrast, a long-term estimate of the pass-through effect for base prices is lower in our case (0.19 compared to 0.26 ).

Similar findings regarding the short-term pass-through effect can be seen when we look at quarterly data. These data show a similar effect on retail prices in our case and in Vilaret and Palić (2006), while the effect on base prices is again lower in our case. Estimates of the long-term pass-through effect on any measure of domestic prices are much lower in our case.

Bearing in mind that the methodologies and sources of data are identical, we can conclude that the short run pass-through effect has been reduced in the most recent period since our data reaches the end of 2007, while the last observation in Vilaret and Palić (2006) is June 2006. Thus, the long-term pass-through effect has been reduced for base prices, while for retail prices the data of different frequencies give different results.

We can see now the results of the estimates from the last eight rows of Table 3 that make the difference between the pass-through effects during the appreciation and during the depreciation (nominal, and real, foreign exchange rate). For example, comparing results with the starting model where we do not control the effects of depreciation, the short run pass-through of the foreign exchange rate on retail prices is about 18 percentage points higher during the depreciation of the foreign exchange rate, while around 18 percentage points are lower during the nominal effective appreciation. Likewise, the long run pass-through of the foreign exchange rate on retail prices is about 50 percentage points higher during the depreciation of the foreign exchange rate, while about 38 percentage points are lower during the appreciation.

Similar results were reached also during the analysis of the base prices and tradable goods prices: pass-through is always higher during the nominal 
Ristanović V., Tasić N.: Exchange rate "Pass-through" on prices in Serbia in the...

depreciation of the domestic currency. Quarterly data provide less clear results, as only pass-through to base prices is higher during depreciation, while the same for retail prices and the prices of tradable goods is not statistically significant.

It is also interesting to see how the pass-through effect changes when we control it for periods of real effective appreciation or depression. For example, comparing the results with the starting model where we do not control the pass-through effect for the effects of depreciation, the short-term passthrough of the foreign exchange rate on retail prices is about 22 percentage points higher during the depreciation of the real effective foreign exchange rate. Similarly, the long run pass-through of the foreign exchange rate on retail prices is about 42 percentage points higher during the depreciation of the real effective foreign exchange rate, while around 38 percentage points are lower during the appreciation. Similar results were reached when we analysed the base prices and prices of tradable goods using monthly and quarterly data: short-term and long-term pass-through is always higher during the real depreciation of the domestic currency. However, quarterly data provide less clear results, so that pass-through on base prices is not statistically significant.

Overall, these results suggest that the effect of pass-through in Serbia is approximately high, but, as in most countries, it is incomplete and lower than 1. Also, when comparing our results with previous studies, we believe that pass-through effect decreased compared to the previous period.

\section{Conclusion remarks}

The pass-through effect of the foreign exchange rate in Serbia is in complete and quite bellow 1 (even in long-term, this effect does not exceed 0.5 when we do not control the depreciation of the exchange rate). However, estimates of this effect are still far relatively high. Nevertheless, our estimates show that the pass-through effect declines in comparison with the past period (if compared with the previous analysis). This finding is consistent, regardless of the applicated methodology.

Estimates obtained using the ADL methodology indicate that the short run pass-through effect is the highest for tradable prices, while the long run passthrough effect is highest for retail prices. Also, all domestic prices respond differently to fluctuates in the foreign exchange rate during the appreciation and during the depreciation of the foreign exchange rate: the pass-through effect is significantly higher during the depreciation of the home currency, while it is lower during the appreciation of the domestic currency. This result is valid for depreciation/appreciation of a nominal and real exchange rate. This 
Ristanović V., Tasić N.: Exchange rate "Pass-through" on prices in Serbia in the...

result is not surprising, taking into account that we can expect prices to move in line with the foreign exchange rate during depreciation (due to the participation of import goods in price indices), while prices are downly rigid during the appreciation.

The foreign exchange rate is still a significant factor of prices/inflation in Serbia. Relatively high estimates of the obtained pass-through coefficient in our case are expected, given that Serbia is a small open economy with a large share of imports in GDP (dependence on imports). Also, the comparably high values of the pass-through coefficient can be interpreted by the low level of competition and the high degree of euroisation. When interpreting the estimates obtained by our analysis, we need to be cautious, because the tendency of the foreign exchange rate variability is relatively low during the period covered by our analysis. This makes it difficult to identify statistically significant links between the foreign exchange rate and other variables.

\section{References}

Adolfson, M. (2007). Incomplete exchange rate pass-through and simple monetary policy rules. Journal of International Money and Finance, 26(3), 468-494. doi:10.1016/j.jimonfin.2007.01.005

Aghion, P., Bacchetta, P., Ranciere, R., \& Rogoff, K. (2006). Exchange Rate Volatility and Productivity Growth: The Role of Financial Development. Cambridge, MA: National Bureau of Economic Research. doi:10.3386/w12117

Bailliu, J., \& Fujii, E. (2004). Exchange Rate Pass-Through and the Inflation Environment in Industrialized Countries: An Empirical Investigation. SSRN Electronic Journal, doi:10.2139/ssrn.560762

-European Central Bank. (2016). Exchange rate pass-through into euro area inflation. Economic Bulletin, Issue 7/2016; European Central Bank.

McCarthy, J. (2000). Pass-Through of Exchange Rates and Import Prices to Domestic Inflation in Some Industrialized Economies. SSRN Electronic Journal, doi:10.2139/ssrn.249576

Frankel, A.J., Parsley, D.C., \& Wei, S. (2005). Slow Pass-through Around the World: A New Import for Developing Countries. NBER Working Paper, No. 11199.

Hellerstein, R. (2008). Who Bears the Cost of a Changein the Exchange Rate?, PassThrough Accounting for the Case of Beer. Journal of Internationa Economics, 7, 6 (1), pp. 14-32.

Kandil, M.E., \& Mirzaie, I.A. (2003). The Effects of Exchange Rate Fluctuationson Output and Prices: Evidence From Developing Countries. IMF Working Papers, 03(200), 1. doi:10.5089/9781451860184.001

Kasa, K. (1992). Adjustment costs and pricing-to-market: Theory and evidence. Journal of International Economics, 32(1-2), 1-30. doi:10.1016/00221996(92)90034-h

Monacelli, T. (1999). Open Economy Policy Roles under Imperfect Pass-Through. New York University. unpublish manuscript. 
Ristanović V., Tasić N.: Exchange rate "Pass-through" on prices in Serbia in the...

Nakamura, E., \& Zerom, D. (2009). Accounting for Incomplete Pass-Through. Review of Economic Studies, 77(3), 1192-1230. doi:10.1111/j.1467-937x.2009.589.x

Newey, W.K., \& West, K.D. (1987). A Simple, Positive Semi-Definite, Heteroskedasticity and Autocorrelation Consistent Covariance Matrix. Econometrica, 55(3), 703. doi:10.2307/1913610

Petrović, P., \& Mladenović, Z. (2005). Modeling inflation in Serbia.

Petrovic, P., \& Mladenovic, Z. (2015). Exchange rate pass-through and the frequency of price adjustment across different inflation regimes. Panoeconomicus, 62(4), 409-427. doi:10.2298/pan1504409p

Smets, F., \& Wouters, R. (2002). Openness, Imperfect Exchange Rate Pass-Through and Monetary Policy. SSRN Electronic Journal, doi:10.2139/ssrn.1703497

Sutherland, A. (2002). Incomplete Pass-Through and Welfare Effects on Exchange Rate Variability. CEPR. Discussion Paper No. 4341.

Tasić, N. (2008). Pass-Through of Exchange Rates to Prices in Serbia. National Bank of Serbia Working papers, No. 10.

Vilaret, S., \& Palić, M. (2006). Exchange rate pass-through effect on prices in Serbia. National Bank of Serbia Working papers, No. 5. 